\title{
Evaluation of Antagonistic Bacillus and Biochar against Soybean Root Rot Caused by Fusarium oxysporum
}

\author{
Fan Yang ${ }^{1,2,3}$, Chunlai Liu ${ }^{2,3}$, Liang Liu ${ }^{2,3}$, Shuang Wang ${ }^{2,3}$, Xifeng Jiang ${ }^{2,3}$, Min $\mathrm{Li}^{2,3}$, Yu Liu ${ }^{2,3}$, Chong $\mathrm{Xu}^{2,3}$, Baohua \\ $\mathrm{Su}^{2,3}$ and $\mathrm{Xinmin} \mathrm{Li}^{\mathbf{1 , 2 , 3 *}}$ \\ ${ }^{1}$ Postdoctoral Programme, Heilongjiang Academy of Agricultural Sciences, Harbin, Heilongjiang Province 150086, P. R. \\ China \\ ${ }^{2}$ Plant Protection Institute, Heilongjiang Academy of Agricultural Sciences, Harbin, Heilongjiang Province 150086, P. R. \\ China \\ ${ }^{3}$ Harbin Crop Pest Scientific Observing and Experimental Station of the Ministry of Agriculture, Harbin, Heilongjiang \\ Province 150086, P. R. China \\ "For correspondence: biology405@126.com \\ Received 26 February 2021; Accepted 25 May 2021; Published 10 July 2021
}

\begin{abstract}
Soybean root rot is a worldwide soil-borne fungal disease threatening soybean production, causing huge losses in yield and quality of soybean. Fusarium species are well recognized as the important causal agent of Fusarium root rot. To screen the beneficial Bacillus strains with capability of suppressing soybean root rot and evaluate the impact of Bacillus combined with biochar against soybean root rot, a pot experiment was conducted with different treatments. In this study, as potential biological control measures, antagonistic Bacillus isolates and different types of biochar were added to soil separately and excellent antagonistic strains mixed with bamboo biochar were applied to the soil. The results showed that seven Bacillus strains promoted the growth of soybean seedlings and reduced root rot severity by 33 to $61 \%$. Bacillus amyloliquefaciens NH2 was associated with the lowest incidence of soybean root rot, indicating its bio-control potential. The value of plant height, root length and plant dry weight of soybean in the sterilized soil mixed with biochar separately treatment were superior to those of soybean in the inoculated with pathogen treatment, especially the bamboo biochar treatment reduced soybean root rot caused by Fusarium significantly and which bio-control efficacy was $77.41 \%$. The soybean plants shoot and root dry weights in the biochar mixed B. amyloliquefaciens NH2 or B. subtilis DBK treatments were increased by $17.1,10.7 \%$ and 19.51 , $19.64 \%$, respectively, which were significantly higher than those of the inoculated pathogen treatment. Compared to antagonistic strain or biochar individual treatments, the disease control efficiency on soybean root rot was up to $64.86 \%$ in NH2 strain mixed with bamboo biochar treatment, which reduced root rot severity significantly and showed a synergistic effect. These results suggest that antagonistic Bacillus strains mixed with biochar can be used as an effective alternative in managing soybean root rot. (C) 2021 Friends Science Publishers
\end{abstract}

Keywords: Antagonistic Bacillus; Biochar; Control efficacy; Soybean Fusarium root rot

\section{Introduction}

Soybean root rot is a soil-borne fungal disease with worldwide distribution, causing a serious damage to soybean production (Chang et al. 2015). There are many species of pathogens causing soybean root rot, among which Fusarium species are well recognized as the main pathogens reported in different soybean-producing regions around the world (Arias et al. 2013a, b). In China, soybean field of the Heilongjiang province accounted for approximate $41 \%$ of total cultivated area and $37 \%$ of gross output (http://www.zzys.moa.gov.cn). As Fusarium root rot complex, it can infect soybean, causing large losses in yield and quality of soybean (Broders et al. 2007; Chang et al. 2018; Wang et al. 2020).

At present, the conventional controlling method, seed coating and field application with chemical fungicide have been widely utilized to reduce and suppress some Fusarium diseases (Wang et al. 2020). Extensive and unjudicial use of fungicides has certain deleterious effects such as evolved resistance in pathogen, environmental pollution and hazard to human health (Wang et al. 2020). Therefore, it is urgent to find a harmless and feasible strategy to suppress the development of Fusarium root rot (Anillo et al. 2019). With the sustainable development of agricultural production, the application of microbial pesticides in agricultural production

To cite this paper: Yang F, C Liu, L Liu, S Wang, X Jiang, M Li, Y Liu, C Xu, B Su, X Li (2021). Evaluation of antagonistic Bacillus and biochar against soybean root rot caused by Fusarium oxysporum. Intl J Agric Biol 26:287-293 
is expanding. Remarkable achievements have been made in the research on rhizospheric growth-promoting bacteria controlling soil-borne diseases of crops and promoting plant growth, among which antagonistic Bacillus strains showed a good potential (Mates et al. 2019; Javed et al. 2021; Sharf et al. 2021).

Bacillus strains are kinds of biological bacteria of plant disease with the widest application and broad application prospect. They not only widely exist in external environments including soil and plant root surface, but also serve as common endophytic bacteria in plant (Xiong et al. 2018). They have both biofertilizer and biocontrol functions, and are the most commonly used in agriculture production (Wu et al. 2019). It is reported that Bacillus with other biocontrol agents brings benefits to the plant, both for growth and nutrition, minimizing the effects of adverse conditions. Therefore, the use of beneficial agents that play on multiple fronts can be considered a useful technological resource for farmers, either by promoting plant growth or by its disease-preventing action (Kalantari et al. 2018; Moreira et al. 2021).

Biochar, a porous form of carbon made from organic waste such as animal dung, animal bones, plant roots, wood chips, crop residues, etc. is increasingly being used as a soil amendment (Bonanomi et al. 2015; Rogovska et al. 2017). The effect of biochar amendments on crop productivity has been still unclear, but has been shown to depend on quality of the biochar (Peterson et al. 2013). Recent studies have suggested that biochar applications may alter the severity of disease caused by foliar and soil-borne fungal pathogens (Elmer and Pignatello 2011; Rogovska et al. 2017) and activate both induced and systemic resistance mechanisms in plants (Rasool et al. 2021). From the first report on the effect of biochar on $F$. oxysporum root rot of lettuce (Matsubara et al. 2008), to the impact on corn stalk rot and soybean root rot (Rogovska et al. 2017; Liu et al. 2019), biochar has shown great potential and strong developmental prospects. This paper aimed to use antagonistic bacteria isolated from the topsoil and rhizosphere soil, and biochar produced from diverse sources, our study is motivated that application of antagonistic Bacillus and biochar to pot experiment can improve soybean growth and reduce severity of $F$. oxysporumroot rot.

\section{Materials and Methods}

\section{Biochar and soil preparation}

Four biochars were used in this study. Rice husk biochar A (Pyrolysis temperature, $500^{\circ} \mathrm{C}$ for $4 \mathrm{~h}$, Shanghai Jiao Tong University). Bamboo biochar B $\left(500^{\circ} \mathrm{C}\right.$ for $4 \mathrm{~h}$, Thermo Fisher Scientific, Inc., Pittsburgh, USA). Rice husk biochar C $\left(500^{\circ} \mathrm{C}\right.$ for $20 \mathrm{~min}$, Energy Research Institute of Heilongjiang Academy of Agricultural Sciences (HAAS). Wheat straw biochar D $\left(200^{\circ} \mathrm{C}\right.$ for $10 \mathrm{~min}$, Energy Research Institute of HAAS). Soil was collected from
Heilongjiang Modern Agricultural Demonstration Area (126.86 N, 45.85 E) in Harbin, Heilongjiang, China. After air-drying the soil and passing it through a $2 \mathrm{~mm}$ sieve, the soil was autoclaved for $2 \mathrm{~h}$.

\section{Pathogenic fungi, antagonistic Bacteria, inoculums and chemical fungicide preparation}

F. oxysporum $\mathrm{M} 3-3 \mathrm{xu}$ (isolated from soybean root rot sample in Northeast China in 2018) was incubated on PDA medium $\left(25^{\circ} \mathrm{C}, 5\right.$ days). Three mycelia plugs were cut out along the colony edges using a $7 \mathrm{~mm}$ hole punch and were inoculated into $\mathrm{PDB}$ medium $\left(25^{\circ} \mathrm{C}, 180 \mathrm{rpm}\right.$ for 5 days) to prepare $10^{6}$ sporesmL $L^{-1}$ suspension. Similar five plugs were inoculated in a $250 \mathrm{~mL}$ sterilized $\left(121^{\circ} \mathrm{C}\right.$ for $\left.40 \mathrm{~min}\right)$ bottle containing $150 \mathrm{~g}$ sorghum grain. The sorghum culture was incubated for 10 days at $25^{\circ} \mathrm{C}$ and shaken daily to ensure uniform fungal growth.

B. subtilis JHK, B. subtilis DBK and B. subtilis N5B8, B. amyloliquefaciens $\mathrm{NH} 2, B$. amyloliquefaciens LFY5 and $B$. amyloliquefaciens BQD1 and B. aryabhattai FY were identified as antagonistic bacteria and were stored in our biological control laboratory. The antagonistic bacteria were inoculated into $\mathrm{LB}$ medium $\left(25^{\circ} \mathrm{C}, 180 \mathrm{rpm}\right.$ for 3 days $)$ to prepare $10^{8} \mathrm{cfu} \mathrm{mL}^{-1}$ bacterial suspension. At the end of fermentation, the suspension of bio-control bacteria was adsorbed onto sterile peat $(1: 1 \mathrm{v} / \mathrm{w})$ and then air-dried to prepare solid bio-control inoculum containing $10^{7} \mathrm{cfu} \mathrm{g}^{-1}$ dry soil. As chemical fungicide, Carbendazim $80 \%$ WP was considered as a control for chemical treatment.

\section{Evaluation of biocontrol Bacillus against soybean root rot}

The experiment was performed to study the effect of 7 species Bacillus strains on the severity of soybean root rot and promoting the growth of soybean. The soil and vermiculite were thoroughly mixed $(1: 2 \mathrm{v} / \mathrm{v})$ and poured into plastic pots with diameter of $11 \mathrm{~cm}$ and height of 11 $\mathrm{cm}$. Soybean cultivar Sui Nong 53 (Heilongjiang, China) seeds were surface-sterilized with $3 \% \quad(\mathrm{v} / \mathrm{v})$ sodium hypochlorite for $3 \mathrm{~min}$, rinsed with sterile water for $5 \mathrm{~min}$ and then five seeds were sown in each pot. All pots were placed in greenhouse. After 10 days, the seedlings were thinned down to three per pot.

The experiment comprised 16 treatments, with three replicates each. \#1 Inoculated pathogen treatment (each pot was irrigated with $30 \mathrm{~mL}$ pathogen spore suspension), \#2 Pathogen with 7 antagonistic strains respectively (after inoculating with $30 \mathrm{~mL}$ pathogen spore suspension 1 day, $40 \mathrm{~mL}$ antagonistic strain suspension was used for irrigation and on the seventh day, the same amount of antagonistic strain suspension was irrigated), \#3Antagonistic strain (same as in \#2) without pathogen spore suspension, \#4Noninoculated control (each pot was irrigated with $40 \mathrm{~mL}$ sterile LB medium). Plants were watered as needed to maintain moisture at $60 \%$ of field capacity. Thirty days after seeding, 
the shoots and roots were oven-dried at $80^{\circ} \mathrm{C}$ for $48 \mathrm{~h}$ and dry weight was determined. Disease severity was rated using the $0-5$ scale. The disease severity index was calculated according to the formula (1), and the disease control efficiency was calculated by formula (2).

Disease severity $(96)=\sum$ (

Disease control efficiency $(\%)=(A-B) / B \times 100$

Where: A - the disease index of the treatment with inoculated pathogen; B - the disease index of each treatment.

\section{Evaluation of biochar amendment against soybean root rot}

The experiment was carried out to study the effect of various biochars on the severity of soybean root rot. Soil and sand were mixed $(2: 1 \mathrm{v} / \mathrm{v})$ and autoclaved for $2 \mathrm{~h}$. The soil-sand mixture was mixed thoroughly with different biochars (20 $\mathrm{g} \mathrm{kg}^{-1}$ dry weigh). Each soil-sandbiochar mixture was inoculated with sorghum inoculum of $F$. oxysporum $\left(30 \mathrm{~g} \mathrm{~kg}^{-1}\right)$. The same amount of noninoculated sorghum mixed with soil-sand mixture was used as blank control. All treatment pots were watered and equilibrated for 10 days before sowing. Soybean seeds were treated as mentioned above (six seedlings per pot). The pots were incubated at $25^{\circ} \mathrm{C}$ and $60 \%$ moisture content (Liu et al. 2019). Each of six treatments was replicated four times. Shoot and root height, length and dry weight were measured 30 days after seeding. The disease index and the disease control efficiency were obtained as specified above.

\section{Evaluation of the effect of bio-control bacteria with biochar on soybean root rot}

Based on the screening and evaluation of the effect of antagonistic bacteria and biochar on soybean root rot, the plant growth experiments with 7 treatments were set up. The experimental treatments were as follows: (1) sorghum inoculum of $F$. oxysporum with solid bio-control agent $(B$. amyloliquefaciens $\mathrm{NH} 2$ and $B$. subtilis DBK respective), (2) sorghum inoculum of $F$. oxysporum with solid bio-control agent (B. amyloliquefaciens $\mathrm{NH} 2$ and $B$. subtilis $\mathrm{DBK}$ respective) and bamboo biochar, (3) sorghum inoculum of $F$. oxysporum, (4) sorghum inoculum of $F$. oxysporum with carbendazim $80 \%$ WP and (5) non-inoculated sorghum as blank control. The application amounts of bio-control agent, biochar and sorghum inoculum of $F$. oxysporum are shown in Table 1. Plants were grown in pots as described above. After sowing, $100 \mathrm{~mL}$ of $80 \%$ carbendazim WP was added to the treatment \#4. Each treatment was replicated three times. Five seedlings were retained in each pot. The disease index, the disease control efficiency and plant dry weight were obtained as detailed above.

\section{Data Processing and Statistical Analysis}

Data were tested for statistical significance using one-way analysis of variance (ANOVA). Mean comparisons were conducted using the least significant difference (LSD) test $(P \leq 0.05)$ (SPSS version 19.0, SPSS Inc., Chicago, USA).

\section{Results}

\section{Effect of biocontrol strains on soybean root rot}

The disease severity index of soybean inoculated by $F$. oxysporum only was above grade 3 (the diseased area accounted for more than $50 \%$ of the total area), and the plant growth was poor (Fig. 1A and B). Compared with blank control, in B. amyloliquefaciens BQD1 treatment assays, the biomass dry weight of soybean was enhanced $17.61 \%$ in terms of promoting growth. The biomass dry weight treated with $B$. amyloliquefaciens $\mathrm{NH} 2$ was 1.2 times of that treated with pathogen in terms of disease prevention. The disease control efficiency of $\mathrm{NH} 2$ strain was $60.61 \%$, which was significantly $(P \leq 0.05)$ higher compared to the others. Bacillus not only controlled soybean root disease, but also promoted plant growth (Table 2).

\section{Biological control of soybean root rot in biochar- amended soil}

The plant height, root length and biomass of soybean treated with bamboo biochar were not significantly different from those of other biochar treatments, but were significantly higher than those of treatment with pathogen inoculation only (Fig. 2 and Table 3). The plant height, root length and biomass of soybean treated with bamboo biochar were 1.29 times, 1.78 times and 1.61 times higher than those of the control inoculated with pathogen. The disease severity index of each biochar treatment was significantly different from that of inoculated control. The disease control effect of bamboo biochar on soybean root rot was $77.41 \%$. The results showed that biochar not only controlled soybean root rot disease, but also promoted plant growth (Fig. 3A and B).

\section{Effect of biocontrol Bacillus and bamboo biochar on soybean root rot and growth}

The shoot and root dry weight of soybean was significantly higher than that of the control when the NH2 and DBK strains were separately combined with bamboo biochar (Table 4). The disease control effect of $\mathrm{NH} 2$ strain combined with bamboo biochar on soybean root rot was $64.86 \%$, which was equivalent to that of the chemical fungicide treatment. Moreover, the root system of soybean was well-developed, the plant growth was robust, and the root rot was not obvious (Fig. 4). 
Yang et al. / Intl J Agric Biol, Vol 26, No 2, 2021

Table 1: Soil treatment and application rate of bio-control bacteria

\begin{tabular}{lll}
\hline Treatment & \multicolumn{2}{c}{ Application rate } \\
\cline { 2 - 3 } & Biological agents $\left(\mathrm{mL} \mathrm{kg}^{-1}\right.$ soil $)$ & ${\mathrm{Inoculum}\left(\mathrm{g} \mathrm{kg}^{-1} \text { soil }\right)}$ \\
\hline $\mathrm{NH} 2+$ pathogen & 20 & 40 \\
$\mathrm{DBK}+$ pathogen & 20 & 40 \\
$\mathrm{NH} 2+$ bamboo biochar + pathogen & 20 & 40 \\
DBK + bamboo biochar + pathogen & 20 & 40 \\
pathogen & - & 40 \\
Carbendazim 80\% WP $(500$ fold solution $)+$ pathogen & 100 & - \\
Blank control & - & \\
\hline
\end{tabular}

NH2: B. amyloliquefaciens; DBK: B. subtilis

Table 2: Soybean growth and the efficacy of root rot control by bacterial bio-control strains

\begin{tabular}{|c|c|c|c|c|c|}
\hline \multirow[t]{2}{*}{ Isolate } & \multicolumn{2}{|c|}{ Shoot dry weight $\left(\right.$ g plant $\left.^{-1}\right)$} & \multicolumn{2}{|c|}{ Root dry weight (g plant ${ }^{-1}$ ) } & \multirow[t]{2}{*}{ Bio-control efficacy $(\%)$} \\
\hline & Pathogen & No Pathogen & Pathogen & No Pathogen & \\
\hline NH2 B. amyloliquefaciens & $1.56 \pm 0.24 a$ & $1.60 \pm 0.13 b$ & $0.37 \pm 0.05 b c$ & $0.34 \pm 0.05 b$ & $60.61 \pm 8.18 \mathrm{a}$ \\
\hline YS7 B. amyloliquefaciens & $1.38 \pm 0.16 b$ & $1.30 \pm 0.11 \mathrm{e}$ & $0.45 \pm 0.06 \mathrm{a}$ & $0.33 \pm 0.06 b c$ & $52.52 \pm 2.31 b$ \\
\hline DBK B. subtilis & $1.31 \pm 0.15 \mathrm{c}$ & $1.45 \pm 0.06 \mathrm{c}$ & $0.39 \pm 0.04 b$ & $0.34 \pm 0.03 b$ & $51.52 \pm 7.33 b$ \\
\hline JHK B. subtilis & $1.13 \pm 0.12 \mathrm{f}$ & $1.27 \pm 0.06 \mathrm{e}$ & $0.27 \pm 0.03 d$ & $0.31 \pm 0.04 \mathrm{c}$ & $33.33 \pm 2.31 \mathrm{e}$ \\
\hline N5B8 B. subtilis & $1.21 \pm 0.30 \mathrm{e}$ & $1.48 \pm 0.11 \mathrm{c}$ & $0.24 \pm 0.03 \mathrm{e}$ & $0.31 \pm 0.05 \mathrm{c}$ & $42.42 \pm 7.33 d$ \\
\hline FY B. aryabhattai & $1.24 \pm 0.16 \mathrm{de}$ & $1.28 \pm 0.07 \mathrm{e}$ & $0.29 \pm 0.01 d$ & $0.31 \pm 0.03 \mathrm{c}$ & $48.48 \pm 11.16 c$ \\
\hline Blank control & - & $1.39 \pm 0.05 \mathrm{~d}$ & - & $0.37 \pm 0.03 \mathrm{a}$ & - \\
\hline Pathogen & $1.28 \pm 0.11 \mathrm{~cd}$ & - & $0.38 \pm 0.03 b c$ & - & - \\
\hline
\end{tabular}

Mean \pm standard deviation

Values within the same column for each parameter followed by letters are significantly different $(P \leq 0.05)$

Table 3: The root rot disease of soybean with different biochar treatments

\begin{tabular}{lll}
\hline Treatments & Disease index $(\%)$ & Bio-control efficacy $(\%)$ \\
\hline Rice husk biochar A & $15.00 \pm 2.89 \mathrm{~b}$ & $70.97 \pm 8.97$ \\
Bamboo biochar B & $11.67 \pm 2.46 \mathrm{~b}$ & $77.41 \pm 3.45$ \\
Rice husk biochar C & $23.33 \pm 4.62 \mathrm{~b}$ & $54.85 \pm 2.77$ \\
Wheat straw biochar D & $16.67 \pm 2.89 \mathrm{~b}$ & $67.74 \pm 5.48$ \\
Pathogen & $51.67 \pm 6.11 \mathrm{a}$ & - \\
Blank control & $1.11 \pm 1.92 \mathrm{c}$ & - \\
\hline
\end{tabular}

Mean \pm standard deviation

Values within the same column for each parameter followed by letters are significantly different $(P \leq 0.05)$

Table 4: Efficacy of biochars with potential bio-control agents in promoting soybean plant growth and controlling disease in greenhouse

\begin{tabular}{llll}
\hline Treatment & Shoot dry weight $(\mathrm{g})$ & Root dry weight $(\mathrm{g})$ & Bio-control efficacy $(\%)$ \\
\hline $\mathrm{NH} 2+$ pathogen & $4.20 \pm 0.36 \mathrm{abc}$ & $1.32 \pm 0.22 \mathrm{ab}$ & $43.66 \pm 14.00 \mathrm{bc}$ \\
$\mathrm{DBK}+$ pathogen & $4.31 \pm 0.85 \mathrm{abc}$ & $1.11 \pm 0.14 \mathrm{bc}$ & $50.62 \pm 10.54 \mathrm{abc}$ \\
$\mathrm{NH} 2+$ bamboo biochar B + pathogen & $4.32 \pm 0.20 \mathrm{abc}$ & $1.24 \pm 0.19 \mathrm{ab}$ & $64.86 \pm 3.64 \mathrm{a}$ \\
DBK + bamboo biochar B + pathogen & $4.41 \pm 0.46 \mathrm{abc}$ & $1.34 \pm 0.17 \mathrm{ab}$ & $58.13 \pm 5.47 \mathrm{ab}$ \\
pathogen & $3.69 \pm 0.07 \mathrm{cde}$ & $1.12 \pm 0.04 \mathrm{bc}$ & - \\
Carbendazim + pathogen & $3.71 \pm 0.26 \mathrm{cde}$ & $1.30 \pm 0.18 \mathrm{ab}$ & $68.13 \pm 5.47 \mathrm{a}$ \\
\hline
\end{tabular}

NH2: B. amyloliquefaciens; DBK: $B$. subtilis

Mean \pm standard deviation

Values within the same column for each parameter followed by letters are significantly different $(P \leq 0.05)$

\section{Discussion}

In our paper, seven antagonistic Bacillus strains were used to evaluate the effect on soybean $F$. oxysporum root rot in pots. The result showed that, compared with the pathogen control, B. amyloliquefaciens $\mathrm{NH} 2$ strain showed its benefits both on promoting the growth of soybean and reducing the disease, which bio-control efficacy reached $60.61 \%$. It is consistent with the previous studies results which proved the Bacillus as potent bio-control agents. The ability of bio-control agents to efficiently colonize surfaces of plant roots is a prerequisite for phytoprotection (Etesami and Alikhani 2018). Bacillus is considered to be a potential bio-control agent because of its wide antibacterial spectrum and strong tolerance to experiment conditions (Kadaikunnan et al. 2015; Zouari et al. 2016).

Four types of biochar were tested in our research in sterilized soil inoculated with $F$. oxysporum. The result showed that the soybean dry weight was higher in the soil-biochar treatment than in the pathogen treatment at the time of investigation. Among them, values of soybean treated by bamboo biochar were superior to others, and the 


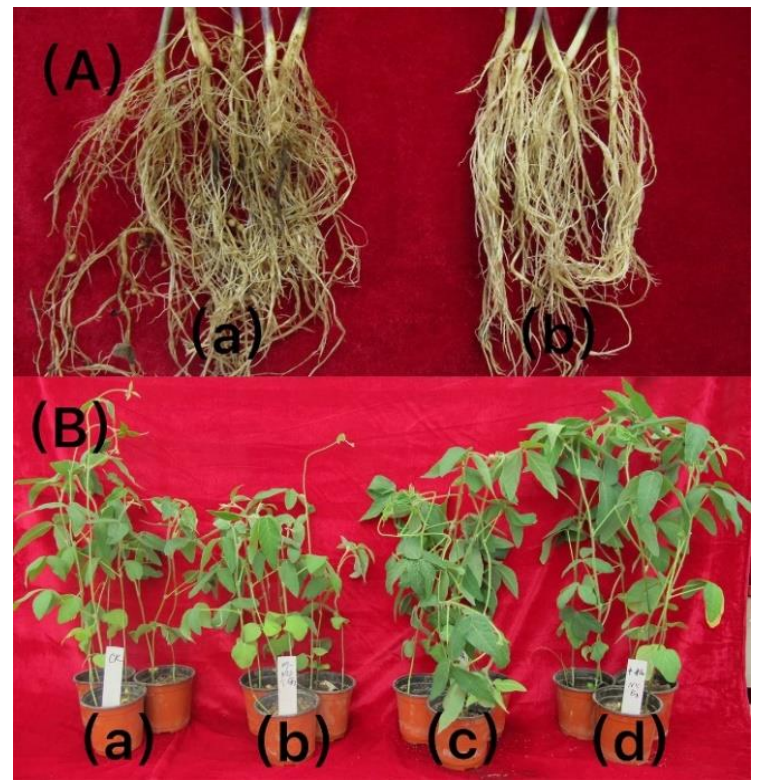

Fig. 1: Efficacy of bio-control agents on soybean root rot and plant growth

(A)-(a) treated by $F$. oxysporum; (A)-(b) treated by $F$. oxysporum with $\mathrm{NH} 2$ strain; (B)-(a) blank control; (B)-(b) treated by $F$. oxysporum; (B)-(c) treated by $F$. oxysporum with $\mathrm{NH} 2$ strain; (B)-(d) treated by $F$. oxysporum with N5B8 strain

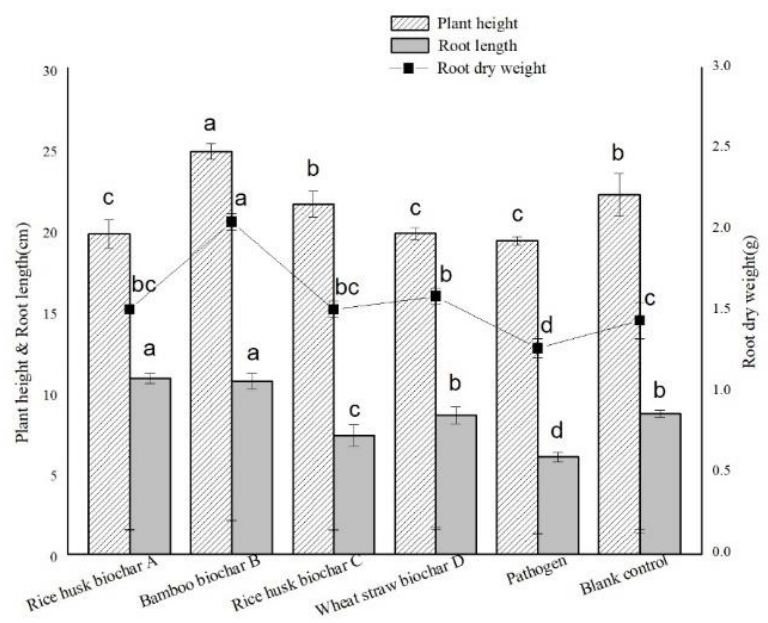

Fig. 2: The growth of soybean plants with different biochar treatments

disease control effect of bamboo biochar treatment was $77.41 \%$. For soil-borne root diseases, it is conceivable that biochars diminish some compounds in the soil solution that might otherwise facilitate the capacity of pathogens to detect and infect roots (Lehmann et al. 2011). Moreover, bamboo biochar significantly reduced the incidence and severity of soybean root rot caused by $F$. oxysporum. The mechanisms that facilitate biochar-stimulated plant protection are still the subject of intensive research (Kolton et al. 2017). The relative abundance of Fusarium spp. in soil decreased with an increase in biochar content, indicating that biochar could reduce the spread of soil-borne plant

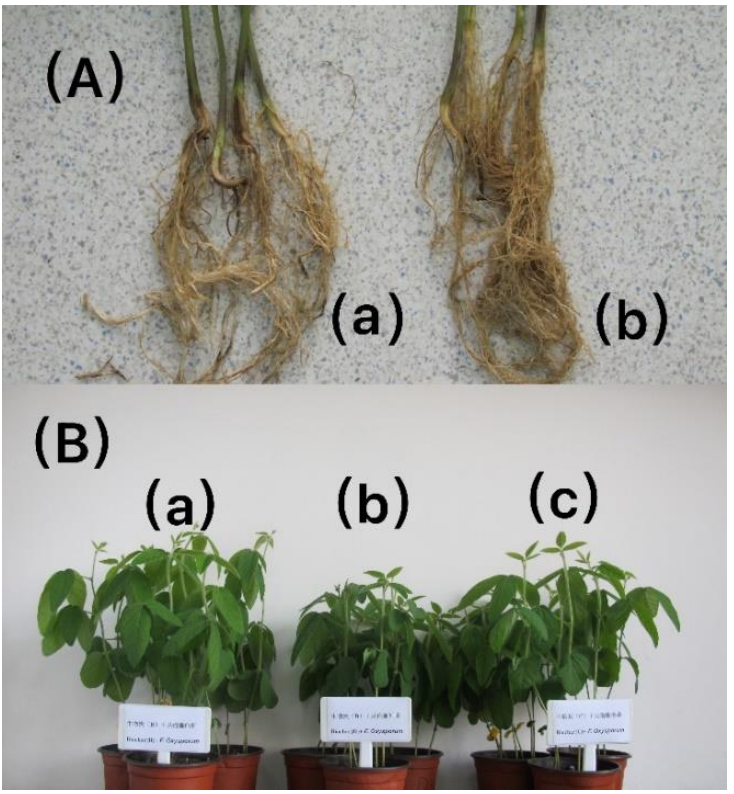

Fig. 3: Effects of biochar on soybean root rot and plant growth (A)-(a) treated by F. oxysporum; (A)-(b) treated by $F$. oxysporum with biochar B; (B)(a) treated by $F$. oxysporum with biochar B; (B)-(b) treated by $F$. oxysporum with biochar D; (B)-(c) treated by $F$. oxysporum with biochar C
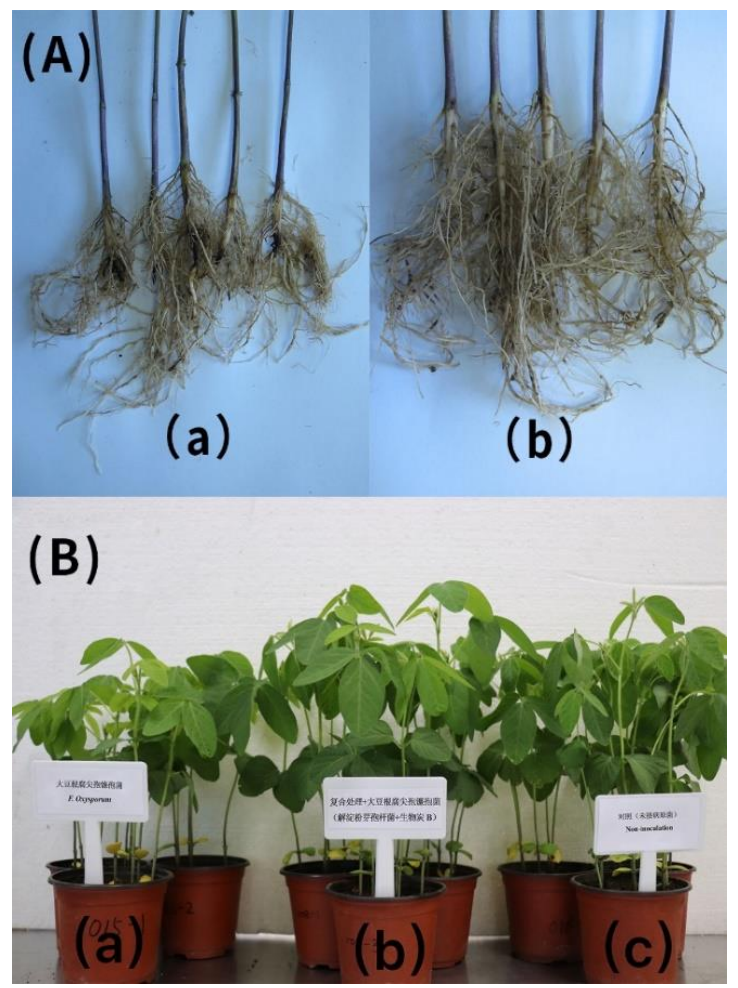

Fig. 4: Efficacy of biochar and antagonistic strains on soybean root rot and plant growth

(A)-(a) treated by $F$. oxysporum; (A)-(b) treated by $F$. oxysporum with $\mathrm{NH} 2$ strain and biochar B; (B)-(a) treated by $F$. oxysporum; $(\mathbf{B})-(\mathbf{b})$ treated by $F$. oxysporum with $\mathrm{NH} 2$ strain and biochar $\mathrm{B} ;(\mathbf{B})-(\mathbf{c})$ blank control

pathogens and inhibit the occurrence of plant diseases (Yao et al. 2017). 
In our study, B. amyloliquefaciens NH2 and B. subtilis DBK were used in combination with bamboo biochar. Compared with the control inoculated with the pathogen, plant dry weight was increased by individual bio-control strains and biochar or the combination of a bio-control strain and biochar. The bio-control efficacy of soybean root rot was up to $64.86 \%$ in combination of $\mathrm{NH} 2$ strain and biochar treatment, which was significantly higher than that of strain or biochar applied separately. Soybean root rot is caused by multiple pathogens. The occurrence of soybean root rot is closely related to the changes in soil microbial community in the soybean rhizosphere. Therefore, it is difficult to achieve the positive effect with a single bio-control agent in practice. Previous studies have shown that the compound bio-control agents that use the synergistic advantages and complementary effects of different functional bio-control strains can achieve the reasonable bio-control effect of soil-borne diseases in crops (Palyzová et al. 2019), indicating the synergism between bio-control Bacillus and biochar.

We used sterilized soil in pot experiments. Compared with the non-sterilized soil mixed with antagonistic bacterial strains mixed with bamboo biochar, the soil microbial system might be relatively simple. It may be the reason why the control effect of different biochar on root rot was different from that of bio-control agent combined with bamboo biochar. In our study, bio-control bacteria and biochar were used to assess the prevention and control of soybean soil-borne root rot. However, further research is needed to clarify the main mechanism and the relevant factors governing biochar control of soil-borne diseases in order to maximize a contribution of each factor in the prevention and control of soil-borne diseases.

\section{Conclusion}

Two main outcomes were documented in our research. First, the combination of $B$. amyloliquefaciens $\mathrm{NH} 2$ strain and $1 \%$ bamboo biochar $(\mathrm{w} / \mathrm{w})$ can promote the growth and biomass of soybean. Secondly, the disease control effect of combined treatment on soybean $F$. oxysporum root rot was $64.86 \%$, which was significantly higher than that of single Bacillus strain or biochar, clearly indicating a synergistic effect.

\section{Acknowledgements}

This paper has been supported by the Research Project of Heilongjiang Academy of Agricultural Sciences (2019YYYF037), the Agricultural Science and Technology Innovation Project of Heilongjiang Academy of Agricultural Sciences Special Plan (HNK2019CX12-14).

\section{Author Contributions}

FY, CLL and XML planned the experiments, LL, XFJ,
YL and BHS investigated and interpreted the results, SW, ML and CX statistically analyzed the data and made original illustrations, FY and XML made the write up.

\section{Conflicts of Interest}

All authors declare no conflicts of interest.

\section{Data Availability}

Data presented in this study will be available on a fair request to the corresponding author.

\section{Ethics Approval}

Not applicable in this paper.

\section{References}

Anillo B, H José, C Garrido, IG Collado (2019). Endophytic microorganisms for biocontrol of the phytopathogenic fungus Botrytis cinerea. Phytochem Rev 19:721-740

Arias MMD, LF Leandro, GP Munkvold (2013a). Aggressiveness of Fusarium species and impact of root infection on growth and yield of soybean. Phytopathology 103:822-832

Arias MMD, GP Munkvold, ML Ellis, LFS Leandro (2013b). Distribution and frequency of Fusarium species associated with soybean roots in Iowa. Plant Dis 97:1557-1562

Bonanomi G, F Ippolito, F Scala (2015). A "Black" future for plant pathology? Biochar as a new soil amendment for controlling plant diseases. J Plant Pathol 97:223-234

Broders KD, PE Lipps, PA Paul, AE Dorrance (2007). Evaluation of Fusarium graminearum associated with corn and soybean seed and seedling disease in Ohio. Plant Dis 91:1155-1160

Chang KF, SF Hwang, RL Conner, HU Ahmed, Q Zhou, GD Turnbull, SE Strelkov, DL Mclaren, BD Gossen (2015). First report of Fusarium proliferatum causing root rot in soybean (Glycine max L.) in Canada. Crop Prot 67:52-58

Chang XL, H Dai, DP Wang, HH Zhou, WQ He, Y Fu, F Ibrahim, Y Zhou, GS Gong, J Shang, JZ Yang, XL Wu, TW Yong, C Song, WY Yang (2018). Identification of Fusarium species associated with soybean root rot in Sichuan Province, China. Eur J Plant Pathol 3:563-577

Elmer WH, JJ Pignatello (2011). Effect of biochar amendments on mycorrhizal associations and Fusarium crown and root rot of asparagus in replant soils. Plant Dis 95:960-966

Etesami H, HA Alikhani (2018). Bacillus species as the most promising bacterial biocontrol agents in rhizosphere and endorhiza of plants grown in rotation with each other. Eur J Plant Pathol 150:497-506

Javed S, A Javaid, U Hanif, S Bahadur, S Sultana, M Shuaib, S Ali (2021). Effect of necrotrophic fungus and $P G P R$ on the comparative histochemistry of Vigna radiata by using multiple microscopic techniques. Microsc Res Technol 84: DOI: 10.1002/jemt.23836

Kadaikunnan S, TS Rejiniemon, JM Khaled, NS Alharbi, R Mothana (2015). In vitro antibacterial, antifungal, antioxidant and functional properties of Bacillus amyloliquefaciens. Ann Clin Microb Antimicrob 14; Article 9

Kalantari S, A Marefat, B Naseri, R Hemmati (2018). Improvement of bean yield and Fusarium root rot biocontrol using mixtures of Bacillus Pseudomonas and Rhizobium. Trop Plant Pathol 43:499-505

Kolton M, ER Graber, L Tsehansky, Y Elad, E Cytryn (2017). Biochar-stimulated plant performance is strongly linked to microbial diversity and metabolic potential in the rhizosphere. New Phytol 3:1393-1404 
Lehmann J, MC Rillig, J Thies, CA Masiello, WC Hockaday, D Crowley (2011). Biochar effects on soil biota - A review. Soil Biol Biochem 43:1812-1836

Liu L, CL Liu, GQ Shen, F Yang, S Wang, XF Jiang, XM Li (2019). Control of Fusarium stalk rot of corn by addition of biochars. Intl $J$ Agric Biol 22:510-516

Matsubara Y, N Hasegawa, H Fukui (2008). Incidence of Fusarium root rot in asparagus seedlings infected with arbuscular mycorrhizal fungus as affected by several soil amendments. J Jap Soc Hortic Sci 71:370-374

Mates APK, NC Pontes, BA Halfeld-Vieira (2019). Bacillus velezensis GF267 as a multi-site antagonist for the control of tomato bacterial spot. Biol Cont 137; Article 104013

Moreira FM, PAR Cairo, AL Borges, LD Silva, F Haddad (2021). Investigating the ideal mixture of soil and organic compound with Bacillus spp. and Trichoderma asperellum inoculations for optimal growth and nutrient content of banana seedlings. S Afr J Bot 137:249-256

Palyzová A, K Svobodová, L Sokolová, J Novák, Č Novotný (2019). Metabolic profiling of Fusarium oxysporum $\mathrm{f}$. spp. conglutinans race 2 in dual cultures with biocontrol agents Bacillus amyloliquefaciens, Pseudomonas aeruginosa and Trichoderma harzianum. Folia Microbiol 64:779-787

Peterson SC, M Appell, MA Jackson, AA Boateng (2013). Comparing corn stover and switchgrass biochar: Characterization and sorption properties. J Agric Sci 5:1-8
Rasool M, A Akhter, MS Haider (2021). Molecular and biochemical insight into biochar and Bacillus subtilis induced defense in tomatoes against Alternaria solani. Sci Hortic 285; Article 110203

Rogovska N, D Laird, L Leandro, D Aller (2017). Biochar effect on severity of soybean root disease caused by Fusarium virguliforme. Plant Soil 413:111-126

Sharf W, A Javaid, A Shoaib, IH Khan (2021). Induction of resistance in chili against sclerotium rolfsii by plant-growth-promoting rhizobacteria and Anagallis arvensis. Egypt J Biol Pest Cont 31:1-11

Wang K, XY Hu, S Yang, KY Xing, X Zhang, L Zhu, XZ Han, YL Xu, W Wei (2020). Impact of long-term chemical fertilizer and organic amendment to Fusarium root rot of soybean. Oil Crop Sci 5:48-53

Wu H, Q Gu, Y Xie, Z Lou, X Gao (2019). Cold-adapted Bacilli isolated from the Qinghai-Tibetan Plateau are able to promote plant growth in extreme environments. Environ Microbiol 21:3505-3526

Xiong GR, GF Zhao, WZ Wang, LB Shen, XY Feng, SZ Zhang (2018). Study on wide antifungal property of Bacillus subtilis HAS. Agric Biotechnol 7:116-117

Yao Q, JJ Liu, ZH Yu, YS Li, J Jin, XB Liu (2017). Three years of biochar amendment alters soil physiochemical properties and fungal community composition in a black soil of northeast China. Soil Biol Biochem 6:56-67

Zouari I, L Jlaiel, T Slim, M Trigui (2016). Biocontrol activity of the endophytic Bacillus amyloliquefaciens strain CEIZ-11 against Pythium aphanidermatum and purification of its bioactive compounds. Biol Cont 100:54-62 